The Labore Journal of Economics

Special Edition (September 2007)

\title{
Pakistan Financial System - The Post-Reform Era Maintaining Stability and Growth
}

\section{Shakil Faruqi*}

\begin{abstract}
The financial system of Pakistan has undergone a sea-change owing to reforms which were implemented over a period of a decade and a half, 1992-2006. The financial system has moved towards promoting the efficiency of financial intermediation while maintaining stability and fostering growth of the economy. Financial repression of the previous decades has receded though it has not been eliminated. Now a shift is warranted for the reform and restructuring of sectoral or sub-sectoral finance which has to be activity based, not institution based. Pakistan's financial system has entered the post-reform era with all its potentials, complexities and challenges. How well the financial system performs in this era depends on how sustainable the financial regime is and how resilient it is in coping with change and financial shocks, both domestic and global.
\end{abstract}

\section{Leading Concerns}

The financial system of Pakistan has undergone a sea-change owing to reforms that were initiated in the early 1990s rather gingerly, but subsequently gathered momentum, culminating in accelerated change in the structure of the financial system and a revamping of the policy and incentive regime that governed its operations. The reform era lasted for nearly a decade and a half, 1992-2006. A great deal has been accomplished during this period as summarized in this paper. There has been a paradigm shift in the financial policy regime that prevailed prior to the reform era and also during the early 1990s. These achievements have occurred amidst powerful economic and financial constraints that have persisted for many years and unprecedented events that have occurred in-between, both domestic and foreign. The financial system has moved towards promoting the efficiency of financial intermediation while maintaining stability and fostering growth of the economy. It is an enviable record of accomplishments by any standard.

\footnotetext{
* Professor, The Lahore School of Economics, Lahore.
} 
Currently, the financial system in its structure, functions and policy regime that governs it is drastically different from what it was a decade ago. With deregulation of the financial regime, financial repression of the previous decades has receded though it has not been eliminated. Purely solvency concerns that dominated much of the 1990s have yielded to concerns of efficiency of financial intermediation and stability of the financial system in the background of a structural shift as well as operational shift discussed below.

\section{A Shift of Focus}

In this sense, the task of macro financial reforms is over, almost, but the task of financial system development is not over and this phase will be no less demanding than the previous phase. Therefore, now a shift is warranted to reforms and restructuring of sectoral or sub-sectoral finance which has to be activity based not institution based. Front line reforms have been the centre of attention of policy makers in the past. The focus now has to be on financial system development under the reformed policy regime and new rules of the game in an environment vastly different from what prevailed before. This shift in focus is also needed because Pakistan's financial system has entered the post-reform era with all its potentials, complexities and challenges. How well the financial system performs in this era depends on how sustainable the financial regime is and how resilient it is in coping with change and financial shocks, both domestic and global; and how good and forward looking is the management of the financial system.

There are two powerful implications concerning the functions and the operations of the financial system. One has to do with the efficiency of transfer of financial resources between suppliers and users within the economy. How well this transfer occurs and on what terms and how efficiently it is performed by the financial system is of immense significance to everyone, be they households, large corporate or small and medium size businesses, or the government and its entities. The second set of implications concern a distorted distribution of resources between various segments of the society resulting from the operations of the financial system, thereby aggravating income distribution patterns that are already stacked against the poorer segments of the society. The mechanisms of resource transfer by themselves are not neutral to the social implications of the transfer.

\section{Challenges in the Post Reform Era - Stability and Solvency}

In managing the financial system during the post-reform era, the main challenge will be that of maintaining stability and sustaining high 
levels of economic growth both over the short run and the long run and sustaining solvency. Short term stability is to be interpreted rather broadly to mean both financial system stability as well as economic stability though both are intrinsically intertwined. Financial system stability encompasses a viable, market-based interest rate structure free of volatile movements, strength and resilience of financial institutions to withstand market swings and external shocks, and stable financial markets free of asset bubbles and gyrations in share prices. Economic stability is largely interpreted as price stability with acceptable levels of inflation, in addition to interest rate and exchange rate stability. It is difficult to argue which one of these is more important and peg the sequencing of corrective actions, though clearly it is difficult to think of economic stability in the face of unstable money and capital markets, or in the face of widespread distress among financial institutions, or both.

Generally, stability of the financial system is largely understood as stability of the banking system only, and seldom does it cross over to concerns of stability of financial markets. Perhaps one of the reasons is that while something can be done to maintain stability of the banking system, and to some extent stability of money and short term debt markets, hardly anything can be done to ensure that capital markets remain stable beyond creating the necessary conditions with routine monetary management, if that.

This is true of nearly all countries across the spectrum, not just developing countries. Monetary authorities find themselves saddled with their mainline responsibilities, and stay away from encroaching upon the operations of capital markets, known to be notoriously fickle and having a mind-set of their own. Further, with all the information flow, their analytical and predictive capabilities, computing prowess for risk and returns, sophisticated derivatives and hedge instruments, capital market participants everywhere find themselves upstaged time and again with large equity price corrections, exploding bubbles, and massive portfolio value losses. They have yet to discover ways to simply foresee market trends, much less devise ways to ensure stability.

The comparative experience demonstrates that in the post-reform era, among newly opened and liberalized financial systems with enhanced exposure to market-based forces, both domestic and foreign, sooner or later both the banking system and financial markets have faced the onset of instabilities that eventually degenerated into financial crises with a rapidity and severity that surprised everyone. The history of the past three decades of the post-reform era among many developing countries that have gone through reform processes, is replete with banking crises or foreign liquidity 
crises, or both. The resolution costs of these crises have been unprecedented in the annals of financial systems. However, this is not to suggest that Pakistan's financial system is ripe for a similar crisis.

\section{Are Reforms Reversible?}

Ordinarily, this would be a moot question, but in the light of historical processes, one can not be so sure. It is possible though unlikely. It is possible because there is a history of system reversals and grand reversals of unprecedented scale in Pakistan. In the 1970s, the government was nationalizing financial institutions including the State Bank of Pakistan (SBP), and ruthlessly rooting out every vestige of private corporation down to puny rice husking and cotton ginning shacks in remote rural areas in the name of socialism. Nearly three decades later, private corporations are being lionized and now the expectation is that they will conduct their business as per international norms of transparency and corporate governance. There remains a sense of uncertainty with investment and business decisions and there is not much commitment to enduring change.

Reversal is unlikely and does not seem to be in the cards given what has transpired and what has been accomplished thus far. It is difficult to think of a return to state intervention and ownership; control and allocation of financial resources that held sway up until the end of 1990s; or that the openness of foreign finance with increasing global linkages will be smothered; or that the structure and apparatus of market-based finance together with a regulatory and supervisory framework and its infrastructure created with such great efforts, will all be bundled up. Yet, an ominous development is the transplanting of centuries old and obsolete modes of finance, reminiscent of barter trade, amidst a modernized system of finance and heralding this as progress. Only time well tell.

\section{Banking System and NBFIs--Evolving Structure in the Post Reform Era}

There have been significant structural changes at the system level in ownership, organization and operations of the banking system and NonBank Financial Institutions (NBFIs) such that the current system hardly bears resemblance to what it was nearly a decade ago. This happened primarily due to deregulation and restructuring not only of the financial system but also of the leading sectors of the economy, restructuring of public sector enterprises (PSEs), the rationalization of prices, interest rates and the exchange rate, and opening up of foreign trade and capital accounts. 
At the system level, changes in the structure of the financial system occurred mainly due to the privatization of financial institutions as reflected in the asset holdings of the public and private sectors over the CY90-05 period; the entry of new commercial banks, both domestic and foreign, new micro-finance banks, and Islamic finance institutions. Simultaneously, reforms and restructuring occurred among the clients of the banking system, mostly PSEs, which facilitated changes in the financial system. Changes in the operations occurred due to the revamping of the policy and regulatory regime governing financial intermediation and deregulation. The directed credit system that prevailed until the mid-1990s with layered allocative targets for specific sectors, sub-sectors or priority categories has been replaced by a market based credit system, and the role of DFIs and specialized financial institutions has been greatly reduced. The interest rate structure and foreign exchange regimes have been liberalized and are market-based, more or less.

\section{Privatization and Deregulation}

The dimensions of structural transformation owing to privatization can be gauged from changes in the ownership structure of assets together with changes in the patterns of financial intermediation and the participation of public and private sector financial institutions. At the system level, in CY90 the share of assets owned by public sector institutions, both banks and NBFIs in the total financial system assets was about $80 \%$, and it dropped dramatically to about $26 \%$ in CY06. The converse holds true for the share of the ownership of private sector banks and private NBFIs over these years. Since the banking system is predominant in the financial system, this shift in the ownership structure was slightly more pronounced, but closely followed this pattern of change.

While the structure of asset ownership thus shifted towards the private sector, the share of the public sector in the use of total financial resources mobilized in the country did not decrease, and this is not reflected by the share of the public sector in banking credit or banking assets alone. The reason is that nearly half of the annual flows of financial resources - the annual flows of financial savings, are being channeled to the public sector. This is being done through public sector borrowings from the financial system, NSS operations which are outside of the banking system but are a part of financial system flows, currency seignorage, and the inflation tax through their own modalities and mechanisms. Consequently, the public sector is still able to garner a hefty share of total financial resources generated in the country through the operations of the financial 
system. The crowding out of the private sector has been mitigated, but only in banking credit, not for resources at the macro financial level.

Privatization, by itself, cannot be successful unless it is accompanied by major initiatives that have to be undertaken in parallel as part and parcel of the financial system reforms. The most important is deregulation involving the elimination of the system of directed credit to market based credit and liberalization of the interest rate and exchange rate regimes as happened in Pakistan during the reform period. To ensure that privatization succeeds, the government undertook the restructuring of financial institutions prior to their privatization, underwrote the massive costs of their restructuring embedded in asset revaluation and employee severance; cleaned up the balance sheet of the dead weight of non-performing loans and other assets of dubious value through massive loan write-offs and provisioning for the NPLs. The government also had to undertake legal reforms, enact new laws or modify the existing laws of exit and entry.

In the glow of the deregulated environment, there is a swing to the other extreme, where deregulation is being interpreted by some bankers as a state of free-for-all. This has made the task of the SBP more difficult. If anything, a deregulated regime has to be more stringent and elaborate in the body structure of its laws, regulations, directives and stipulations than a controlled regime for the reason that the task of maintaining order and stability in an open market environment and free of financial distress is more difficult. The rules of the game have to be charted out over and over in an iterative fashion in an ever-changing environment until they come to grips with market realities. A delicate balance has to be struck between lack of rules and over-regulation. It is a delicate and complex task.

\section{Consolidation or Fragmentation?}

The number of bank and non-bank financial institutions is still large even though there have been some buy-outs and mergers and the entry of new banks has become more difficult given substantially increased minimum capital requirements discussed below. The number of banks is roughly the same it was five years ago. In 2005, the banking system comprised 44 institutions. Among these, 35 were commercial banks including 4 stateowned banks, 20 local private banks, and 11 foreign banks. In addition, there were 5 micro-finance banks and 4 specialized banking institutions, ZTBL being the largest. The number of NBFIs, is much larger, 160 as of last count, and their number has increased over the past five years in spite of closures, mergers and buy-outs. These include five Development Financial Institutions (DFIs), 8 investment banks, 20 leasing companies, 31 
modarebas, 40 mutual funds, 52 insurance companies including 48 domestic owned and 4 foreign owned, 3 housing finance companies, 3 venture capital companies, 3 discount houses and more than 400 brokers.

The sheer number of financial institutions, therefore, remains unwieldy and it is not healthy for the structure since it has led to the fragmentation of the banking system and NBFIs. Entry into NBFIs continues unabated, such as the new banks or finance companies which are ensconced in their niche markets, providing housing finance, consumer finance or Islamic finance. These new and old entrants, together, are marginal players in the financial system given the size of their operations relative to the mainline banking institutions as discussed below. They have ended up enhancing fragmentation because they perform similar services to existing institutions, just more inefficiently, and have a potential for mismanagement or overexposure to various risks which may cause serious financial losses and ultimately become a source of instability at the system level.

Currently, the entry of Islamic finance and micro-finance institutions is being heralded as the start of a new era in Pakistani banking and in some ways it is, given that their entry is driven by societal preferences of one kind or the other. But it is not going to help with the diversification of the banking system given that they are likely to remain appendages of financial intermediation for a long time to come. Diversification does not occur just because the number of financial institutions has increased, rather it occurs primarily when new institutions or old ones launch new business operations, introduce new products such as term lending, and begin to cover new segments of clientele. Therefore, in open financial systems, what matters is activity-based rather than institution-based diversification.

\section{Concentration or Competition?}

A look at business shares shows that banking is concentrated among the top five commercial banks who dominate the banking system in every category while the remaining banks are small players. Four of these are: NBP, HBL, UBL, MCB. The fifth one was ABL until recently and has now been displaced from fifth position by Alfalah Bank. The dominance of these five banks has diminished over the past years; yet, their combined assets are slightly more than half of the assets of the banking system; so are the proportions of their deposits and advances in the banking system. But the combined NPLs of the original five banks were higher, about three fourths of total NPLs of the banking system until a couple of years ago. 
The financial strength of the banking system, therefore, is closely tied to the financial fortunes of these large five banks. They are the price setters; while at the same time in the past, many of them were loss leaders as well. Their profitability and solvency is of systemic significance to the banking system and hinges upon the efficiency of their operations and cost effectiveness, risk management, credit outreach and their business diversification. Impetus for future improvements will come from institutionspecific initiatives concerning meaningful capacity building and change management. This will happen mainly owing to pressures of profitability and efforts to maintain their relative market shares. A direct role of the SBP or the government in this arena is no longer material as it was in the past.

\section{Financial Intermediation - Structural Change and Growth}

The core function of financial intermediation in Pakistan remains with the commercial banks, not the NBFIs, and this is unlikely to change in the future. The assets of the NBFIs, both state-owned and private, as a proportion of total assets of the financial system steadily declined from $24 \%$ in 1990 to $11 \%$ in 1995 , mainly owing to the closure or privatization of DFIs, or because of a much faster growth of private banks as a group as compared to the growth of private NBFIs as a group, regardless of the spectacular growth of some segments of the NBFIs such as leasing companies or Islamic finance companies.

This decline in the asset share of the NBFIs is reflective of a faster decrease in the share of advances, since loans outstanding are the largest part of assets of a financial institution any time. In 1990, advances of the NBFIs were $27 \%$ of financial system advances, and declined to $7 \%$ last year. If we add Islamic finance, this proportion increases slightly. Currently, deposits of the NBFIs as a group are a minuscule proportion of the total financial system deposits, at about $2 \%$. If we add the deposits of Islamic finance, this proportion increases to about 3\%. For these reasons, the focus has to be on the operations of the banking system. The role of NBFIs has been marginalized no matter what indicator is used and they are not significant for the future of the financial system of Pakistan.

The deregulation of the interest rate structure occurred gradually and the regime has undergone a significant change during the reforms from administered rates to market-based rates. This transition was not smooth as there was periodic volatility in interest rates but not destabilizing movements. This is a considerable achievement of the monetary authority, the SBP, when observed in the light of comparative experiences of financial reforms in similar phases in other countries. The SBP discount rate has now 
firmly established itself as the anchor rate for the banking system after several iterations and fine tuning of auction mechanisms during the 19972002 period.

As regards the long term trend of interest rates on the lending side, the weighted average lending rate of commercial banks was rising throughout much of the 1990 s and reached a peak of about $16-17 \%$ in the late 1990s, though this weighted average hides a significant variation of up to $20-22 \%$ on the high side. Thereafter, these rates began to decline and reached their lowest point of about $7-8 \%$ by CY04. Since then, lending rates began to rise again and currently they range between $10-12 \%$ for mainstream borrowers and $15-17 \%$ for fringe borrowers.

The trend of interest rate changes on the deposit side is similar. There was significant volatility over the reform period. The weighted average deposit rate through much of the 1990s ranged around $8 \%$. Towards 1999, a slide of major proportions occurred and the weighted average deposit rate fell drastically to about $2 \%$ by 2004 . Since then deposit rates have recovered to about $4 \%$ currently. Deposit rates of NSS have also fallen from $14 \%$ to $10 \%$ for long term mainline instruments over the same period and are about $9 \%$ currently.

Thus far, the banking system has withstood volatility of interest rates and has emerged with stronger earnings and profitability through managing associated interest rate risks. As for lending, it is unclear how much of the banking system loan portfolio has been rebalanced with the current structure of interest rates - the financial liability related turnover of credit, because borrowers effectively recycle the shorter loan maturities relatively easily than their medium to long term maturities, which are a small proportion of the commercial banks' portfolio.

There has been a strong growth of deposit mobilization by the financial system, inclusive of NSS during 1995-2005 averaging at about $15 \%$ per year. The rate of growth of deposits during CY90-CY00 was $12 \%$. Later on, during $\mathrm{CY} 00-05$, this rate slowed down to $11 \%$. In part, this growth occurred because of phenomenal growth of NSS deposits at an average annual rate of $24 \%$. As it was, banking system deposits also increased at the rate of $9 \%$ annually over the CY95-00 period. Subsequently, this situation reversed; during CY00-CY06 the annual growth rate of banking system deposits nearly doubled to $16 \%$ while that of NSS dropped to $7 \%$. If NSS deposits are set aside, then practically deposit mobilization by the banking system is all that matters at the financial system level while shares of NBFIs and Islamic banks remain at about $3 \%$ and are inconsequential. Deposit 
taking activities of fringe segments such as finance companies, Islamic banks, micro-finance banks and NBFIs do not hold much potential for bringing about structural changes at the system level.

One could argue that NSS operations are not financial intermediation, NSS instruments are not deposit instruments, and deposits mobilized by the NSS are a part of government operations of unfunded debt, not deposit mobilization as such, and these deposits are an expensive way of debt financing. That is largely the case because as the SBP estimates show, if the government had borrowed Rs. 230 billion through the financial market instead of NSS during FY02, it would have saved about Rs 11 billion in borrowing costs per year. The NSS, therefore, is neither a low cost borrowing source, nor a debt management system but has led to distortions in savings mobilization because of its negative impact on banking system deposits, though institutional depositors are now banned from investing in NSS instruments.

There has been significant growth of financial system credit throughout the reform period, accompanied by structural changes in the sources of credit along the privatization patterns. During much of the 1990 s, the rate of growth of credit remained fairly stable at around $9 \%$ per year, but during CY00-05, this rate increased to about $12 \%$ per year with significant volatility from year to year. This expansion of credit at the financial system level mirrored patterns of growth of banking credit but in an accentuated pattern in the late reform period. The average annual growth of banking credit during the decade of CY90-00 was about $11 \%$, and thereafter rose to about $16 \%$ during CY00-05. Lately, there are signs of a slowing down of credit expansion amidst rising interest rates. Nonetheless credit expansion is occurring at a record rate of growth. The issue is whether these spectacular increases in banking credit can be sustained, and if so, does it represent an exception to the trend, or is it the vanguard of a structural change in bank lending that was the expected outcome of decade long financial reforms and dissipation of financial repression.

There has been a reversal both in the sources of credit and allocation of credit between the public sector and the private sector owing to privatization, deregulation and the elimination of a layered system of credit allocation that prevailed earlier. At the start of reforms, in CY90 the proportion of credit extended by public sector banks was $86 \%$, while the share of credit extended by private sector banks was only $14 \%$. Later on, the share of private sector banks began to rise and by CY00 it was about $42 \%$, and then it jumped to about $80 \%$ in CY06 in the wake of the privatization of UBL and HBL. There was a corresponding decrease in the share of credit 
extended by public sector banks over the same period. As regards allocation and use of credit, the share of private sector borrowings from the financial system was $55 \%$ in CY90, and slowly rose to about $60 \%$ in CY00, and then jumped to $71 \%$ by CY06, representing a significant change in uses of credit over the patterns that prevailed before.

A major issue concerning the credit system is overdraft lending which is preponderant with short term maturities, and there is not much term lending in the system. One could argue that overdraft lending with variable interest rates is effectively term lending given the perpetual rollover of loan maturities at call, but that is stretching the point. Overdraft borrowing has a higher repayment flow than contractual term-borrowing with or without variable interest rates. Hence, term lending is more conducive for promoting longer term investments. This is the same rationale that underpinned the DFIs' era in Pakistan in the 1950s and 1960s and also in other developing countries.

Overdraft lending creates a bias in favor of large, well-heeled corporate borrowers - the premium borrowers with substantial cash flow potential. Almost all banks prefer premium borrowers to extend large loans, thereby keeping their banking risks and cost fairly low, and are averse to diversifying their client base in favor of small and struggling new borrowers who are left high and dry. This is why SME lending, or micro-credit has not made significant inroads in the mainline banking system, not only in Pakistan but in many developing countries as well. This has forced the authorities to revive SME banks, and offer incentives for the establishment of micro-finance institutions and to revive housing finance. These are issues of sectoral finance which need an in-depth evaluation.

As a result of the above, there is loan concentration since the large amounts of credit flow to premium borrowers, though it has diminished somewhat with the drive to bring in new borrowers whose number has increased substantially. By implication, the amount of banking credit extended to medium and small borrowers is fairly low. In this regard, lending practices of banks in Pakistan are similar to those in other countries. There is also sectoral concentration of banking credit which has always persisted both in the pre-reform and post-reform period. The textile sector is the major borrower as traditionally it has been, and its share in total banking system credit has ranged between $25-31 \%$, followed by consumer credit whose share was about $10 \%$. In contrast, the share of agriculture sector credit has been less than $10 \%$, and the share of trade credit to exports and imports about $8 \%$ in recent years. 
In spite of attention given to housing finance, the proportion of house building finance remains an insignificant fraction at only about $2 \%$ of banking system credit as compared to $12-18 \%$ in Asian countries and 25$35 \%$ in advanced countries. Until some years ago, the housing sector was classified by many commercial banks as an unproductive sector, even though there are roughly 38 industries whose growth is directly linked to housing construction and is a leading indicator in advanced countries to gauge the performance of the economy over the short term. Mortgage lending is beset by two issues: the prime one is the bankability of property collateral tendered and the mismatch in the maturity structure of bank funding and house building loans of long term maturities.

\section{Post Reform Era - Management of Financial System}

The objectives of managing the financial system are to maintain stability, growth, soundness and solvency which boils down to maintaining the sustainability of the financial system. These issues have been front line concerns of the SBP and form the core of its strategic objectives. These are: maintaining price stability with growth, broadening the access of borrowers to banking credit and the provision of financial services, ensuring the soundness of the financial system, exchange rate and foreign exchange reserve management, and the strengthening of the payments system. Stability is the prime focus of monetary management, while soundness and solvency are the prime focus of banking supervision and regulation, though there is no hard and fast division as such. The practice turns out to be that way.

Review and analysis of financial reforms in Pakistan and their impact has already been done in an exhaustive fashion in the series of the Financial Sector Assessment (FSA) reports and Banking System Review (BSR) reports launched by the SBP nearly five years ago. These two annual series are unique in that hardly any central bank among developing countries has undertaken this task as systematically as the SBP has done over the past five years. At the start, the focus was on the impact of reforms on the financial system. It has now shifted to maintain the soundness of the banking system as viewed through $C A M E L$ indicators, and the evaluation of improvements in the system of banking supervision and regulation.

The focus of maintaining soundness and solvency centers around what the banking system does, given that on the intermediation side its role is overwhelmingly significant. The front line issue is how the banking system has fared thus far regarding soundness and solvency, and what are the prospects in the post-reform era? In this sense, managing a financial system 
is more than simply monetary management, though it is a critical element in maintaining stability and fostering the growth of the economy.

For maintaining stability and fostering growth, the foremost issue is what are the remaining distortions or weaknesses in the financial system, how significant they are, and where do they originate from? The issue for the policymakers is what is the nature of future interventions, and how to balance them with economic and social priorities? What are the intervention points, and how effectively can those be managed in fast moving financial markets, both domestic and global. The complexity of these issues will grow, not diminish, as the financial system progresses and becomes more sophisticated in a fairly open and liberalized financial regime.

On the financial markets side, the main objective is to keep money and capital markets stable and avoid volatility, swings and market corrections, if that can be achieved, though markets have a way of surprising everyone. Financial market behavior is notoriously unpredictable and there is not much that can be done to avoid periodic episodes of swings or even volatility in financial market prices and transactions. Therefore, maintaining the stability of interest rates, prices and exchange rates is regarded as a necessary condition for the stability of financial markets; that is the role of the SBP, while maintaining orderliness, participation, transparency and the integrity of financial market operations is the role of the SECP at a time of open capital accounts and FDI inflows.

\section{Financial Deepening and Growth}

A widely used indicator of financial system growth is the M2/GDP ratio because $\mathrm{M} 2$ is a reflection of resource mobilization of the financial system, and are liabilities of the financial system. After all, M2 is basically currency, a statutory but non-binding liability of a central bank while deposits are liabilities of the banking system. The larger the M2, the larger is the magnitude of macro-financial resources mobilized. Conversely, in repressed financial regimes with relatively low levels of financial deepening roughly at one third of GDP, economic growth would be stifled compared to what it would have been otherwise. This is the prevailing view of financial deepening.

During the second half of the 1990s, the M2/GDP ratio in Pakistan was nearly stagnant at about $37 \%$, then jumped to around $44 \%$ during the last five years. This is a reflection of the extraordinary growth of deposits over the last six years. This seven point move of the M2/GDP ratio within a relatively short period of five to six years does not imply that a structural 
change of this magnitude has erupted from within the economy. For one, a good deal of increase in this ratio owes to expansion of net foreign assets and a large part of the economy still remains undocumented and operates outside the financial system.

Currently, Pakistan's M2/GDP ratio is much lower than that prevailing in other Asian countries. In 2005, this ratio in India was 67\%; in the Philippines 53\%; in Thailand 96\%, and in Malaysia, 106\%. Therefore, there is ample room for further increase in the M2/GDP ratio and growth. This shows that the necessary conditions for future development of the financial system have largely been taken care of and now is the time to tackle sufficient conditions through diversification and consolidation of the banking system, restructuring of priority sector financing at the sectoral level, capacity building, and corporate governance of financial institutions. The reliance on the M2/GDP ratio to gauge the depth of financial intermediation is weak and may be supplemented by looking at the trends on the asset side, the asset/GDP ratio, which has increased from $54 \%$ in the mid-1990s to about $62 \%$ currently. This ratio also reconfirms that financial deepening has a long way to go to reach levels observed in many countries where it exceeds $100 \%$.

\section{Monetary Management - Stability}

It is in this background that we need to have a look at monetary management in Pakistan. Overall, the SBP has been very successful at monetary management over the past years and has been attuned to the needs of maintaining stability at a time of transformation within the banking system and volatility in financial markets. The SBP has achieved a skillful switch-over from a system of direct monetary controls that prevailed until the late 1990s to the deployment and calibration of indirect monetary instruments in a liberalized environment such as cash reserve requirements (CRR), statutory liquidity requirements (SLR), SBP discount rates, and open market operations. More importantly, reserve money has finally acquired the backing of large foreign exchange reserves, which was not the case some years ago. The role of the interest rate has been enhanced after the withdrawal of the Credit Deposit Ratio (CDR) as the leading instrument of credit control. Therein lies the shift from a direct to indirect system of monetary management.

The SBP has also been quite successful in steering a tight or easy monetary policy stance during the past four years as warranted by short term trends and has established good operational mechanisms. The movements in the structure of interest rates has followed a monetary policy 
stance over the past years, by and large, led by the SBP discount rate which has always been a powerful tool of monetary management. The banking system is responsive to signals conveyed by the monetary authority though there is periodic slack in the speed of adjustments and there are rigidities.

These elements have helped to keep inflation under control and maintain price stability over previous years, though the price level has been under severe pressure for the past couple of years. The rate of inflation declined steadily from about $13 \%$ in FY95 to about $3 \%$, then to $9.3 \%$ in FY05. Since then, there has been some moderation in the levels of inflation but it remains a major concern as inflation currently is about $7 \%$. Historically, inflationary pressures originated mainly from fiscal deficits and the consequent monetary expansion by the then banking system to meet public sector borrowing needs, and the same pattern prevails today given soaring levels of fiscal deficits from Rs 134 billion in FY04 to Rs 325 billion in FY06.

A good part of inflation during the 1990s occurred from imported inflation and steady depreciation of the exchange rate. These pressures were mitigated over the past few years but now have re-emerged as fiscal deficits and current account deficits have continued to rise substantially. The issue is: what are the threats to price stability and how serious are they? And how far will monetary policy be able to cope with these pressures in the future? In such circumstances, the SBP had no option but to pursue a tight monetary policy, which it has over the past couple of years, though the SBP realizes that it has to strike a balance between inflation and growth; has to moderate pressures on the exchange rate while keeping interest rates stable. However, in times of swiftly rising fiscal deficits and large inflows of FDI, a restrictive monetary stance can go only so far in maintaining short term price stability, together with exchange rate and interest rate stability.

In spite of an open foreign trade regime, liberal incentives for export, a market determined exchange rate and a large foreign exchange reserve position, current account deficits have returned with a vehemence that is reminiscent of the old days, to a record level of \$5 billion in FY06 and is likely to be higher in FY07, since the trade deficit in the first nine months of this fiscal year is approaching nearly $\$ 9$ billion. The silver lining is that foreign exchange reserves of about $\mathrm{U} \$ 13$ billion are sufficient for nearly a year of imports rather than for just a few weeks as in the past.

The SBP has been successful in maintaining exchange rate stability, over the past five years together with a strong foreign exchange reserve 
position which began building up from a modest level of US\$ 1.35 billion in CY00, to around US\$ 13 billion currently under the free floating foreign exchange rate and inter-bank foreign exchange market. There have been periodic ups and downs but in a narrow band. Recently, there has been a noticeable increase in the inflows of FDI, but nearly a third of it is in onetime foreign exchange privatization proceeds which will not recur. There is also growth of portfolio investment, but nowhere near the levels that occurred in East Asian or Latin American countries, whose abrupt return became the cause of a full blown crisis for them. There are no FDI induced bubbles to cause worry, though the capital market boom is beginning to look like a bubble situation.

Comparative experience has demonstrated that attempts to stabilize or to maintain some targeted level of the exchange rate by central banks have been unsuccessful. Some of the spectacular failures were in the early 1990s when the Bank of England tried to maintain the parity of the British pound and then had to withdraw after staggering losses within a matter of a few days. Subsequently, Bank Negara Malaysia tried to do the same, and suffered heavy losses with stunning rapidity. It is now firmly understood that foreign currency trading to corner the global currency market is suicidal which has a turnover approaching two trillion dollars per day. Therefore, maintaining the stability of the exchange rate through currency market manipulation when the Pakistani rupee is being traded actively is not an option available to the SBP except in a narrow band and for short duration.

This perception of monetary policy management amidst conflicting objectives is familiar among countries at similar stages of financial reforms. After the era of the control regime is over and the external sector is liberalized, the monetary authorities can pursue either domestic price stability or exchange rate stability, but not both with the same degree of success. Once the financial system is liberalized and financial markets begin to assert their role, and large inflows from overseas begin to occur with open trade and capital accounts, be they remittances or FDI, price and exchange rate stability then become difficult to maintain simultaneously, because the opening of capital accounts reduces the influence of the monetary authorities on interest rates and hence its capacity to affect aggregate spending.

If the authorities pursue exchange rate stability to stabilize foreign exchange inflows and keep the current account balance intact, the domestic interest rate and price stability comes under pressure because of the sterilization of FDI and other foreign currency inflows, no matter how it is done. Conversely, if they shift to maintain interest rate and price stability, 
sooner or later the exchange rate comes under pressure. For example, in times of inflation, if the monetary authority were to raise interest rates and they become higher than the international rates, it will encourage capital inflows and will depress the real exchange rates.

\section{Banking Regulation and Supervision - Solvency}

Improvements in the system of banking regulations and supervision at the SBP has been one of the leading items from the start of the reform period and it has paid rich dividends. Since then it has undergone a significant transformation and the system that prevails today is far superior than it was at the start of the reforms. Its procedures and practices have been modernized and these are as sophisticated as one would expect to find anywhere among the leading countries. The process is supported by the installation of an upgraded payments system, IT facilities at the SBP as well as at leading banks, thereby significantly improving the speed and accuracy of financial information flow so vital for banking supervision.

A major change from the old to the new is transparency in the processes of supervision and regulation as to what is being regulated and why and by whom. There hardly was any meaningful information flow in the public arena concerning the operations of financial institutions, much less on the state of their financial health or their relative standing with regard to impaired capital and other systemic weaknesses that were at the root of their financial distress. This information flow, together with the analysis and evaluation of financial institutions, started with the launching of annual series of FSA and BSR reports. This transparency is critical in the postreform era if stability, soundness and solvency of the financial system are to be achieved.

Nearly all banking and financial crises that have erupted during the previous decades, occurred in countries which had a well established system of supervision and a full awareness of the potential for crisis. It seems that no amount of banking supervision is sufficient enough to prevent the emergence of crises, and that is a sobering thought. In times of financial distress, banks and quasi-banking institutions have a way of going belly-up, not because of any lack of supervision, but mainly because of excesses of placements, untenable risk exposure, and herd behavior in garnering golden opportunities of profit or large capital gains in a red-hot market, be it the loan market, financial market, exchange market, or real estate market. That is why there is such rapidity in the onset of the crises and its monumental dimensions, once it unravels. This has happened in developed countries such as Japan and the US during the 1990s when a few large commercial banks 
became insolvent and before any remedial action could be taken, they had folded up, in spite of an enviable system of information flow and a modern supervision system.

Similarly, the Mexican crisis of the mid-1990s and East Asian crisis of the late 1990s happened even though their banking supervision and regulation systems and the sophistication of bankers and financiers and their expertise in handling capital inflows was regarded at par with international standards. They also had the knowledge and experience of similar crises that erupted previously. What went wrong and why so swiftly? The post-crisis diagnosis reveals that one of the common elements is herd behavior and overexposure of a speculative variety in a few sectors in anticipation of more than normal market returns. As soon as the inflow began to dry out, the specter of foreign exchange illiquidity loomed large, and investors wanted to exit before imminent devaluation of the Mexican peso in the face of foreign currency illiquidity. This mass exit of foreign capital, the reverse flow, is akin to a bank run domestically. There is no safeguard against it, much the same way as there is no safeguard against a bank-run on any given day.

Further, good bankers have been known to become bad bankers, and this process unfolds right under the nose of bank examiners and supervisors. Spotting this trend is difficult; it is a matter of experience and ultimately it is a judgment call. This has happened time and again in developed and developing countries alike. How it happens is explained briefly below. Why it happens boils down to the inability of bankers or financiers to keep a lid on acceptable business risks, and tame these risks when they get out of line, but well before they are beyond any reprieve. This is a precarious rope walk. There is always an unwillingness to close losing operations, take early losses and quit in the early stages when these losses are still smaller than later on when the crisis erupts full scale.

The instinct of the bankers is to keep the borrowers alive through recycling and renewals of bad loans into loans, a window dressing exercise; or worse yet, advancing additional fresh loans to effectively insolvent borrowers to tide over what is perceived as cash flow problems and imminent illiquidity, thereby getting deeper into financial distress. In this sense, insolvency occurs first, illiquidity follows later. The borrowers are already in deep distress by then, and they are well past the stage of routine rescue operations because their illiquidity originates not from their routine business turnover and cash flows, but rather from structural weaknesses in their operations. The same occurred in the nationalized banking era in Pakistan when banks kept bailing out insolvent PSEs, lending more 
intentionally because of collusion or bad judgment, or on government directives, then writing off the loans while the banking supervision outfit was alive to these perils.

\section{Soundness and Solvency - the Banking System}

Maintaining soundness and solvency of the financial system has been the uppermost concern of the SBP. The BSR reports of SBP are focused on the latest developments in the leading indicators of soundness of the banking system, based on timely reporting by financial institutions, required under disclosure laws and regulations. The analytical approach is the CAMEL framework which is a rating system of financial institutions. The evaluation of the banking system's soundness, as given in the SBP reports, clearly shows that financial strength and soundness of the banking system has considerably improved as evidenced by various soundness indicators at the system level, and its capability is fairly strong to withstand various types of shocks within plausible limits. It may, however, face difficulties in extreme situations, the probability of occurrence of which is largely remote.

Among the soundness indicators, the first one is capital adequacy inclusive of minimum capital requirements and an assessment of the ratio of capital to risk weighted assets. For years, the minimum paid up capital requirement was fairly low at around Rs. 500 million, and was raised to Rs. 1 billion in 2002 and again to Rs. 2 billion in 2004. This increase in paidup capital together with cleaning up of the loan portfolio was the main element in reducing the risk factor in assets, and has led to a significant improvement in the risk weighted capital adequacy ratio, a statutory obligation for all banks regardless of their ownership.

Since the time the SBP began publishing soundness indicators in its FSA and BSR reports covering the period CY97-05, the data shows a significant improvement in the Capital Adequacy Ratio (CAR). In 1997, it was $4.5 \%$ for all banks, and jumped to $11 \%$ within a year, and since then has stayed at around the same level, though there have been variations from year to year. For state owned banks, private banks and foreign banks, the same pattern prevailed. There were annual variations in between, but the ratio remained fairly high and was not a cause for concern. In contrast, this ratio for specialized banks has never recovered from negative levels.

As part of the Basel II implementation, the banks are required to further increase their paid-up capital by Rs one billion per year until they reached Rs 6 billion by the end of 2009 by all banks and DFIs. This is an unprecedented increase in base capital. After the increase materializes by 
2009 , the CAR for banks will range from $8 \%$ to $14 \%$. The shift to such levels of capital adequacy is the first insurance against the insolvency of financial institutions, and once the range is reached, solvency at the system level is assured. A swift rise of minimum capital requirements to such levels, however, would be a powerful barrier to entry for new banks seeking incorporation, though not for non-bank entities which are incorporated under the companies charter. These requirements will discourage not only the entry of new banks, but will also hurt competition, and will encourage non-bank companies to enter the NBFIs group which is likely to add to the fragmentation of the financial system.

\section{Burden of NPLs - Asset Quality}

The asset quality indicator revolves around the proportion of risk weighted assets or the proportion of non-performing loans (NPLs) in total assets. These ratios indicate that there are no threats to solvency of the banking system that loomed large during much of the 1990s mainly due to the rise of NPLs. The management of NPLs by the banking system has considerably improved over the past years, and the burden of NPLs does not pose a threat to the solvency of the banking system, large though it is. There has been a reduction in NPLs from an all time high of Rs 244 billion in CY01 to Rs 184 billion in CY06 largely because of the resolution of loan defaults, loan write-offs and several recovery drives. The proportion of NPLs in the total loans of the banking system has fallen from about $24 \%$ to about $8 \%$ in CY06. A great deal of provisioning has been done by the banks since the early 1990s and the total amount is estimated at Rs 139 billion in CY06. The amount of net NPLs, therefore, has decreased from Rs 92 billion in CY97 to Rs. 45 billion in CY06; their proportion in banking credit has likewise decreased significantly.

Hence, NPLs are no longer a systemic risk as they were in the 1990s. The solvency risk has been mitigated, though NPLs remain a drag on the profitability of leading banks and this situation will persist in the future. The resolution of problem banks, likewise, is no longer a pressing issue as it was during the 1990s when a large part of the banking system was in financial distress. There are now only three problem banks and they do not pose a systemic threat. Private banks are likely to impose a much tighter discipline on lending practices to prevent the incidence of loan defaults, but how far new NPLs will be contained remains a concern given the recently reported rise of defaults. The culture of default may have been weaned but has not disappeared. It will take a long time before good borrowing behavior is restored coupled with good lending behavior as well. 


\section{Intermediation Costs and Spreads - Efficiency}

The intermediation cost is not a CAMEL indictor, but it reflects the operating efficiency of banks though only on the funding side since it is the ratio of administrative expenses to the average amount of deposits and borrowings of a financial institution. BSR estimates show that intermediation costs during the late 1990 s was about $3.5 \%$, and then began to decline and is currently around $2.7 \%$. This suggests that banking efficiency improved at least on the funding side over the late reform period, but still it is above the cost range prevailing in comparator countries at around $2.0 \%$, and is much higher than the range of 1.5 to $2.0 \%$ observed in leading countries.

These intermediation costs are exclusive of provisioning costs for NPLs. Provisioning for NPLs adds close to one percent to banking intermediation costs over and above the current level of $2.7 \%$. This is a major reason for high intermediation costs, especially for the recently privatized large banks. Part of the cost of provisioning and equity replenishments have been assimilated and recycled into the balance sheets of financial institutions thereby raising the costs of operations and thus intermediation costs, which refuse to be compressed beyond current levels.

Banking spreads have remained around 7\% during most of the 1990s and have remained around the same over the recent period, even higher, at around $8 \%$. This is not surprising because structural changes in the credit system occurred concurrently to significant volatility, both in the deposit rates and lending rates over the reform period discussed earlier. The concern that banking spreads are high is valid, but in a deregulated system there is hardly much that the monetary authority, the SBP, can do to help reduce the spread since it is embedded into the bank funding structure on one side, and into lending operations and investments on the other.

\section{Profitability - Banking System}

Recently, commercial banks have returned to profitability after persistent losses for many years, though specialized banks are still unprofitable. There has been an astounding increase in profitability which has mitigated but has not eliminated the specter of insolvency at the system level, though not at the institutional level. Nothing prevents a single financial institution becoming insolvent while the rest of the banking system is doing well and is profitable.

Profitability may be gauged through the return on asset (ROA) both before and after tax, or return on equity (ROE) before and after tax, or the 
ratio of net interest income to gross income, or the cost income ratio. All these indicators unanimously show a marked improvement during the CY9705 period in the profitability of the banking system in Pakistan. After tax ROA for the banking system was negative until CY01 and then turned positive and swiftly rose to the current levels of about 2\%, ahead of international benchmarks. After tax ROE likewise was negative until CY01, but thereafter it became positive and shot up to $26 \%$ in CY05. This jump is a one time phenomenon and is unlikely to be replicated in the future, though it is a broad indicator of a trend towards profitability. Net interest income as a proportion of gross income showed a remarkable increase from $49 \%$ in $\mathrm{CY} 97$ to $72 \%$ in CY05, owing to the scissor like pattern of interest rates on deposits and lending over this period discussed earlier.

A number of factors have contributed to enhanced profitability. Banks were able to lower their interest expenses faster than the decline in their interest income owing to low borrowing needs, re-pricing of their interest bearing liabilities and a large growth in non-interest income from investments and other assets over the past few years. In addition, improved operating and business practices and financial services, restructuring and reorganization and downsizing, staff reduction, branch closures, tightened internal costs, and controls on administrative expenses have helped to reduce their operating costs. Above all, a decline in the corporate taxes on banking business from $56 \%$ to $42 \%$ have improved after tax profits, and will get a further boost when the tax rate is lowered to $35 \%$. Specialized banks have continued to suffer heavy losses throughout this period and their profitability indicators never returned positive. Lately, their losses have narrowed down but profitability remains as elusive as ever.

\section{Managing Banking Risks}

In the above context, the issue is how well the banks are able to manage banking risks with market-based interest rates, floating exchange rates and exposure in the foreign exchange reserve position, open external accounts, increased participation in FDI and capital inflows. The pattern of credit risk in routine bank lending to sectors of the economy has not changed much. If anything, it has increased owing to a move to new lines of lending such as consumer credit; but as long as exposure of the banks remains concentrated towards prime borrowers, this shift in the profile of credit risk will be manageable. If credit risk is not managed properly it eventually shows up in NPLs, or the concentration of banking credit in a few sectors of the economy, or in a few segment of borrowers, or a rising proportion of riskier loans in its portfolio during times of rapid expansion of banking credit. 
Exchange rate risk concerns the exposure of banks on their foreign exchange liabilities. The banking system was shielded from exchange rate risk in the past owing to a number of explicit and implicit safeguards extended to them by the SBP in return for their surrendering their foreign exchange inflows, be they on FCAs, remittances, or export earnings. All this has changed since then in the new foreign exchange regime whereby commercial banks are practically on their own with regard to foreign exchange risks on their reserves, exporters' balances, foreign currency deposits, foreign exchange loans extended to the foreign companies or customers, and on their portfolio related operations in the foreign exchange markets.

The impact of interest rate risk is on the portfolio of the bank, both investment portfolio and loan portfolio, and is central to asset/liability management at the institutional level. The impact of interest rate changes is severe if there is a serious mismatch of maturity structure between the loan portfolio and deposit portfolio because of a significant divergence in interest rates associated with these maturities. Unless the bank is able to compensate on both the asset and liability sides of its balance sheet, it is likely to suffer a loss. Interest rates were falling during most of the CY95-03 period, and then they stabilized. During this period, the overall profitability of banks was not compromised. Thereafter, when interest rates began to rise over the past two years, this was accompanied by a significant growth in banking profits to record levels. This indicates that during both periods, banks were able to absorb the impact of interest rates on their portfolio, be it the investment portfolio or loan portfolio.

Likewise, banks have been able to manage the equity price risk over this period. The sustained fast growth of stock market and equity prices continues unabated, and it has further accelerated this year. The SBP placed a cap on the direct exposure of banks in stock market placements estimated at about Rs. 35 billion in CY05, though it has grown further since then. This exposure of the banking system in equity investment is not a cause for concern, because the share of direct exposure in total investments held by the banking system remains small. The indirect exposure through carry-overtransactions, badla financing, was about Rs. 8 billion in $\mathrm{CY} 05$, and since then it has decreased further owing to restrictions placed on badla financing. In view of this structure of the banking system's exposure in the equity market, the degree of equity price risk is not a major concern.

From the point of view of soundness, the proposition that banks become insolvent first and illiquid later is likely to generate much debate among bankers and financiers. No matter how one perceives it, liquidity 
risk has to be managed well. Since the observance of liquidity levels is a statutory obligation, and the SLR is closely monitored by the SBP, the banking system has to keep adequate liquidity levels all times in compliance of the SLR. Observance of the SLR by itself does not eliminate liquidity risk which has emerged for the banking system partly from inflation, and partly from the rapid growth of banking credit. Currently, liquid assets are nearly one third of total assets, and this is a reasonably comfortable position for the banks; their liquidity position is in excess of the statutory requirement.

\section{Banking System - Sensitivity to Shocks and Stress}

The crux of the management of the soundness and solvency of the banking system, to the extent that it can be system analyzed, is to enhance its resilience so that it can successfully absorb moderate levels of financial system shocks and moderate levels of economic instability, while operating in the market environment with open capital accounts and a vibrant external sector. To assess the resilience of the banking system, the SBP conducted its own stress tests as reported in the BSR05 involving 12 largest banks. The exercise covered all three market risks, namely the interest rate, the exchange rate and equity price risks, and a fourth one as well, the liquidity risk. Four stress scenarios were developed for each of these risks and their impact was estimated on the combined profitability and capital of these banks as an approximation to the impact at the system level. The results show that among these four risks, the liquidity risk is relatively more worrisome and the impact of a shock is more severe because liquidity margins are thin if the liquid assets exclude near-liquid government securities. If these are included, the amounts of liquid assets with the banks increase and consequently liquidity shocks are not so severe.

Stress tests of credit risk shocks show that the degeneration of position of NPLs is not a material threat to their solvency; it is manageable and banks will be able to withstand a degeneration of their portfolio quality except for extreme situations which are unlikely to occur. The impairment of the quality of the portfolio is exhibited in rising levels of NPLs. Test results show that the capital adequacy of these banks will be unimpaired and they will be able to tolerate a $10 \%$ increase in their NPLs together with a $50 \%$ degeneration of their loan portfolio into classified loans. Further, if the ratio of NPLs to loans currently estimated at $6.7 \%$ were to degenerate to as much as $33.5 \%$, only then will it wipe out the capital of these banks, meaning that banks are fairly strong and their solvency will be at stake only in extreme cases of far-out shocks. 
Similarly, the impact of shocks of upward interest rate movements together with parallel shifts of the yield curve on the value of the bank's portfolio is tolerable, except for a large shock in the case when interest rate increases by 100 basis points or 200 basis points and there is a parallel shift and flattening of the yield curve. The impact on gross income is more pronounced and the percentage loss is substantial. The shock of a decrease in equity prices, that is, a fall in the stock price index in the range of 20$40 \%$ will also not have much of a negative impact on the banks, and banks will be able to ride out these adverse movements.

The shock of exchange rate movements is more manageable because the foreign assets of banks are larger than their foreign currency liabilities. Therefore, a depreciation of the exchange rate of as much as $25 \%$ does not have any negative impact on their capital; in fact their CAR appreciates. Their borrowers, however, will face difficulties in loan servicing of foreign credits; therefore the value of their foreign currency loan portfolio will decrease. If there were to be an appreciation of the exchange rate by $20 \%$, it will lower the rupee value of their assets and their CAR will decline but only slightly. It seems that banks are resilient enough to absorb shocks of any combination of exchange rate movements within these ranges together with the counterpart impact of exchange rate changes on their clients. There is a corroboration of the central conclusion of these SBP tests with those of the IMF-WB FSA05 report based on its own sensitivity and stress tests. Their results show that Pakistan's financial system is resilient enough to absorb various types of moderate shocks and there is no imminent threat, except in situations where several types of shocks may occur simultaneously and in combination, though the report does not elaborate upon the combination or their severity.

\section{Looking Ahead}

The future of financial system development will in good part depend on capacity building and improved corporate governance. Capacity building needs priority attention because it is not a once for all activity, rather it is a continuous process. As soon as one threshold is scaled, another one looms on the horizon owing to fast moving changes in the business world and also in the financial system owing to increasing global linkages. Hence, the need for continuous revival and rejuvenation from within at the institutional level will always be there if the dynamism of modern banking is to be internalized.

Further gains in efficiency and improvements in the operations of the banking system simply can not be achieved without adequate investment and efforts at capacity building. Frontline institutions have already gone 
through a few rounds of their capacity building led by the SBP, which embarked on this process some years ago with considerable success. Many small private banks and foreign banks went through capacity building efforts of their own and completed their transition earlier on during the late 1990s. Recently, privatized large banks embarked on their capacity building a few years ago and they are in the midst of catching up to their fast growing needs.

There are three main elements to capacity building. These are: improvements in management orientations and dynamism, investment in training, and investment in infrastructure such as IT facilities in parallel with IT training if this investment is to yield dividends. All the three elements are a relatively recent experience for Pakistani banks, but these are not unfamiliar or new to them. Investment in training, unfortunately is still regarded as an administrative expense rather than investment in human capital. That mind-set has not changed. Currently, most institutions spend only a fraction of their routine administrative budget on training, perhaps no more than $3 \%$ of their annual administrative outlays and it is not considered as investment in human capital.

Further, training is widely interpreted as improving basic skills or is regarded as improving abilities in procedures as compared with functional training. For example, training a branch manager is not the same as training a banker; or for that matter, training a central banker, say, in currency regulations is not the same thing as preparing someone to become a central banker. This involves the enhancement of capabilities, re-orientation of the mind-set and attitudes which are much harder to come by. Functional training was not needed in a nationalized system, directed as it was from the centre, or so it seems. That is why training came to a grinding halt and with it the culture of self-improvement at the institutional level disappeared. In the current business environment financial institutions cannot prosper without sustained efforts at capacity building. 


\section{References}

Balino, Tomas J. T., and V. Sundararajan, 1986, Financial Reform in Indonesia in H. S. Cheng (ed.), Financial Policy and Reform in Pacific Basin Countries. Massachusetts: Lexington Books.

Barth J, Litan R., Lessons from Bank Failures in the United States, in Hunter Caprio and Leipziger (eds.), Preventing Bank Crises: Lessons from Recent Global Failures, Federal Reserve Bank, Chicago, EDI/World Bank Development Studies, pp 133-172.

Bernanke, Ben, 1990, "Financial Fragility and Economic Performance." Quarterly Journal of Economics.

Bery, Suman, India: Commercial Bank Reform, in Hunter Caprio and Leipziger (eds.), Preventing Bank Crises: Lessons from Recent Global Failures, Federal Reserve Bank, Chicago, EDI/World Bank Development Studies, pp 243-260.

Bydalek, P., Lessons from Recent Global Bank Failures: The Case of Brazil, in Hunter Caprio and Leipziger (eds.), Preventing Bank Crises: Lessons from Recent Global Failures, Federal Reserve Bank, Chicago, EDI/World Bank Development Studies, pp 249-254.

Caprio, Gerard, 1992, "Policy Uncertainty, Information Asymmetries and Financial Intermediation,” Working Paper, PS 853, World Bank.

Caprio, Hunter, Kaufman, and Leipziger (eds.), 1998, Preventing Bank Crises: Lessons from Recent Global Failures, Federal Reserve Bank, Chicago; EDI/World Bank Development Studies.

Chang, Roberto and Andres' Velasco: The Asian Liquidity Crisis Federal Reserve Bank of Atlanta, Working Paper 98-11, July 1998.

Cho, Yoon-Je, 1986, "Inefficiencies from Financial Liberalization in the Absence of Well-functioning Equity Markets." Journal of Money, Credit, and Banking 18 (May): 191-9.

Corbo, Vittorio, Jaime de Melo, and James Tybout, 1986, "What went wrong with recent reforms in the Southern Cone," Economic Development and Cultural Change (Apri1): 607-40. 
Crockett, Andrew: Global Capital Markets and Stability of Banking and Financial System, in Hunter Caprio and Leipziger (eds.), Preventing Bank Crises: Lessons from Recent Global Failures, Federal Reserve Bank, Chicago, EDI/World Bank Development Studies, pp 89-105.

de Juan, Aristobulo, 1987, "From Good Bankers to Bad Bankers," (mimeo) EDI/World Bank.

de Juan, Aristobulo, 1988 "Does Bank Insolvency Matter and What to Do About It,” (mimeo) World Bank.

Diaz-Alejandro, Carlos, 1985, Goodbye Financial Repression, Hello Financial Crash Journal of Development Economics 19, pp 1-24.

Dooley, Michae1, Globalization, Speculative Bubbles and Central Banking, pp 103-112 in Faruqi, S. (ed), 1992, Financial Sector Reforms in Asian and Latin American Countries; Lessons of Comparative Experience, EDI /World Bank, Seminar Series.

Dooley, Micheal, Globalization, Speculative Bubbles and Central Banking, pp 103-112 in Faruqi, S. (ed), 1994, Financial Sector Reforms, Economic Growth and Stability.

Enoch, Charles, and Green, John (eds), 1997, Banking Soundness and Monetary Policy Issues and Experiences in the Global Economy, IMF Institute, Washington DC.

Ezaguirre, Guillermo, Financial Crisis, Reforms and Stabilization: The Chilean Experience, in Hunter Caprio and Leipziger (eds.), Preventing Bank Crises: Lessons from Recent Global Failures, Federal Reserve Bank, Chicago, EDI/World Bank Development Studies, pp 147-162.

Faruqi, Shakil (ed), 1992, Financial Sector Reforms in Asian and LAC Countries; Lessons of Comparative Experience, EDI/World Bank, Seminar Series.

Faruqi, Shakil (ed), 1994, Financial Sector Reforms; Economic Growth and Stability EDI/World Bank, Seminar Series. 
Franke1, Jeffrey, Preventing Banking Crises, in Hunter Caprio and Leipziger (eds.), Preventing Bank Crises: Lessons from Recent Global Failures, Federal Reserve Bank, Chicago, EDI/World Bank Development Studies, pp 3-12.

Hasan, Pervez, 1998, Pakistan's Economy at the Cross Roads, Oxford University Press.

Husain, Ishrat, 2001, Pakistan - Economy of An Elitist State, Oxford University Press.

Husain, Ishrat, 2003, Economic Management in Pakistan, Oxford University Press.

Kane, Edward, Understanding and Preventing Bank Crises, in Hunter Caprio and Leipziger (eds.), Preventing Bank Crises: Lessons from Recent Global Failures, Federal Reserve Bank, Chicago, EDI/World Bank Development Studies, pp 269-278.

Kiriwat, Ekamol, Securities Market Regulation and Reforms in Thailand, in Hunter Caprio and Leipziger (eds.), Preventing Bank Crises: Lessons from Recent Global Failures, Federal Reserve Bank, Chicago, EDI/World Bank Development Studies, pp 139-144.

Lin See Yan, The Institutional Perspective of Financial Market Reform, The Malaysian Experience, in Hunter Caprio and Leipziger (eds.), Preventing Bank Crises: Lessons from Recent Global Failures, Federal Reserve Bank, Chicago, EDI/World Bank Development Studies, pp 215-248.

Lindgren, CJ: How to Keep Banking System Sound in Period of Change, in Hunter Caprio and Leipziger (eds.), Preventing Bank Crises: Lessons from Recent Global Failures, Federal Reserve Bank, Chicago, EDI/World Bank Development Studies, pp 271-286.

Sachs, Jeffrey, Tornell, Aaron, and Andres' Velasco, "The Collapse of Mexican Peso” NBER Working Paper 5142, June 1995.

Sheng, Andrew, 1993, Bank Restructuring: The International Experience. World Bank.

State Bank of Pakistan, Banking System Review (Annual), various issues.

State Bank of Pakistan, Financial Sector Assessment (Annual), various issues. 
State Bank of Pakistan: Annual Reports (Annual) various issues.

Truman, Edwin, What Can and Should Be Done to Prevent Future Financial Crises? in Hunter Caprio and Leipziger (eds.), Preventing Bank Crises: Lessons from Recent Global Failures, Federal Reserve Bank, Chicago, EDI/World Bank Development Studies,

Williamson John, Commonalities, Mistakes, and Lessons Viewed from a South Asian Standpoint, in Hunter Caprio and Leipziger (eds.), Preventing Bank Crises: Lessons from Recent Global Failures, Federal Reserve Bank, Chicago, EDI/World Bank Development Studies, pp 287-294. 